\title{
Prelude to a Collaboration: Dostoevsky's Aesthetic Polemic with Mikhail Katkov
}

\author{
Susanne Fusso*
}

As the editor of the Russian Herald, Mikhail Nikiforovich Katkov was one of the most important figures in the development of the nineteenth-century Russian novel. Fathers and Sons, the first parts of War and Peace, Anna Karenina, and the major novels of Dostoevsky all appeared in the pages of his journal. But it seems impossible for us to evaluate his role without emotional distortion. Our understanding of Katkov's literary activity and contribution has been greatly complicated by his vigorous political activity. In parallel with his literary efforts, as the editor of the newspaper the Moscow News he was a towering political figure who advocated Russian nationalism and autocracy and agitated vigorously against radical and revolutionary movements. Because of this, seventy years of Soviet-era Russian literary history had to treat him as persona non grata. His literary role was consistently minimized or presented in its most unfavorable light. The situation in the West has been somewhat similar. Throughout the twentieth century, Western literary scholars tried to take a critical, objective approach to the ideologically constrained productions of Soviet scholars while

* Forthcoming in Editing Turgenev, Dostoevsky, and Tolstoy: Mikhail Katkov and the Great Russian Novel by Susanne Fusso; reprinted with permission from Northern Illinois University Press. Copyright (C) 2017 Northern Illinois University Press. 
still relying on their formidable archival, historical, and philological resources. No matter how critical one's approach, it was very hard not to be influenced by the incessant negativity surrounding the image of a figure like Katkov (a negativity that he in many ways deserved). I am working on a study of Katkov's literary activity, in particular his relations with Belinsky, Evgeniya Tur, Turgenev, Dostoevsky, and Tolstoy. My plan is to offer a view of Katkov's literary activity that avoids the two extremes of pariah and paragon, giving him his due as the important figure he was, without vilification or canonization.

Of all Katkov's relationships with Russian writers, his association with Dostoevsky was perhaps the most important and lasting relationship of his literary career. Dostoevsky published all his most celebrated novels in Katkov's Russian Herald (founded in 1856): Crime and Punishment (1866), The Idiot (1868), The Devils (1871-72), and The Brothers Karamazov (1879-80); his seminal Pushkin speech was published in Katkov's newspaper the Moscow News in June 1880, six months before Dostoevsky's death. ${ }^{1}$ Dostoevsky's letters from 1865 on make it clear that he relied on Katkov for virtually continuous financial support through payment of advances on his work in progress. Yet their relationship began inauspiciously in 1858-59, with Katkov's rejection of Dostoevsky's novella The Village of Stepanchikovo and Its Inhabitants, and continued in the form of a fairly rancorous polemic between the two men, carried on in the pages of their respective journals in 1861-63.

Dostoevsky and Katkov had very little face-to-face contact, even during the years of their most intense collaboration. We have quite a few letters from Dostoevsky to Katkov, but not many from Katkov to Dostoevsky have survived. So the journalistic polemic offers us a chance to study a kind of dialogue between the two men, a dialogue that preceded a long and productive working relationship. In their skirmishes over aesthetics, in general, and Pushkin, in particular, one can see not only their vehement clashes but also the points of inner, fundamental agreement that can help us understand what made possible

1 The only lengthy novel that Dostoevsky published elsewhere was A Raw Youth (Podrostok, 1875), which he published in Notes of the Fatherland. Whether coincidentally or not, this novel is considered the least successful of Dostoevsky's major works. The pioneering study in English of Katkov's literary career is by Catharine Theimer Nepomnyashchy, "Katkov and the Emergence of the Russian Messenger," Ulbandus Review, no. 1 (1977): 59-89. See also E. V. Perevalova, Zhurnal M. N. Katkova "Russkii vestnik" v pervye gody izdaniia (1856-1862): Literaturnaia pozitsiia (Moscow: Moskovskii gosudarstvennyi universitet pechati, 2010). 
their fruitful, if sometimes contentious, partnership. In this chapter I will touch on a few of the highlights of this complex interaction.

Toward the end of Dostoevsky's nine years of imprisonment and exile in Siberia that began in 1849, as he was trying to reenter Russian literary life from a seemingly unbridgeable distance, he turned to the Russian Herald, which he referred to in a letter of 1857 as "indisputably the primary Russian journal at the present time.”2 In 1858 Dostoevsky requested and obtained an advance from Katkov for his work in progress, one of the first two works he wrote after prison, The Village of Stepanchikovo. But after he had submitted the manuscript and asked for a higher honorarium than he and Katkov had agreed to, the Russian Herald rejected the work in 1859. One can hardly be surprised by this: both Village of Stepanchikovo and "Uncle's Dream," the other work written in Siberia, can be seen today as eccentric masterpieces, but in genre and tone they are farcical and unrealistic, more suited to the 1840 s than to the atmosphere of social and political ferment represented by the Russian Herald.

Dostoevsky was personally stung by the difficulty of his reentry into Russian literary life. In a letter to his brother Mikhail of October 1859, he despairs about the negotiations with another editor, Nikolai Nekrasov of the Contemporary, the man who had been Dostoevsky's first editor in $1846 .{ }^{3}$ Dostoevsky suspects that Nekrasov had made inquiries at the Russian Herald on the sly, that they had told him "the grapes were sour," and that Nekrasov was consequently offering insultingly low terms for publishing his novella (PSS,

2 F. M. Dostoevsky, Polnoe sobranie sochinenii v tridtsati tomakh [PSS], ed. V. G. Bazanov et al. (Leningrad: Nauka, 1972-90), 28(1):288 (letter of November 3, 1857, to M. M. Dostoevsky); hereafter cited as PSS by volume and page. William Mills Todd III is completing a study of the poetics and pragmatics of serialization in the nineteenth-century novel, and he has discussed Dostoevsky's working relationship with Katkov in several articles: "The Brothers Karamazov and the Poetics of Serial Publication," Dostoevsky Studies 7 (1986): 87-97; "Dostoevsky's Russian Monk in Extra-Literary Dialogue: Implicit Polemics in Russkii vestnik, 1879-1881,” in Christianity and the Eastern Slavs, vol. 2 of Russian Culture in Modern Times, ed. Robert P. Hughes and Irina Paperno (Berkeley: University of California Press, 1994), 124-33; "Dostoevsky as a Professional Writer," in The Cambridge Companion to Dostoevsky, ed. W. J. Leatherbarrow (Cambridge: Cambridge University Press, 2002), 66-92; and "Tolstoy and Dostoevsky: The Professionalization of Literature and Serialized Fiction," Dostoevsky Studies 15 (2011): 29-36.

3 Poor Folk (Bednye lyudi) first appeared in Nekrasov's Peterburgskii sbornik (St. Petersburg, 1846). 
$28[1]: 346)$. Dostoevsky goes on to speak of himself as a "proletarian," dependent on the good will of editors: "But besides all these intrigues with the Russian Herald, Nekrasov is a sensitive animal. After finding out the story with the Russian Herald and knowing that I, after returning from Siberia, have spent all my money and am in need, how can he not propose to such a proletarian a reduction in price? 'He'll agree without fail!' they think" (ibid.). Indeed, according to an associate of Nekrasov, he disliked the novella and said, "Dostoevsky is all used up. He won't write anything more" (28(1):507). For the man who was among the first to recognize Dostoevsky's genius to say such a thing was a devastating indicator of how far Dostoevsky had to go to regain his literary position. In the end, the novella was published in A. A. Kraevsky's journal Notes of the Fatherland in 1859.

The rejection of Village of Stepanchikovo seemed to tell Dostoevsky something important about how to connect with a Russian audience in the reformist age that followed the death of Nicholas I in 1855. In 1859, in the same letter to his brother in which he lamented the rejection of Village of Stepanchikovo by the Russian Herald and spoke of the "powerful moral abasement" caused by Nekrasov's haggling (PSS, 23[1]:346), he announced a new project: Notes from the Dead House, based on his life in the Siberian prison: "My personality will disappear. It is the notes of an unknown man; but I guarantee its interest. The interest will be of the most capital sort" (28[1]:349). This work, published in the journal Time that Dostoevsky started with his brother in 1861 upon his return to St. Petersburg, connected powerfully with a reading audience eager for information about previously hidden sides of Russian life. It reestablished Dostoevsky as a major writer. ${ }^{4}$ Katkov's rejection has to be seen as one of the factors that ignited Dostoevsky's desire to write a new kind of novel, one that engaged intimately with current Russian events.

Editing his own journal seemed to offer Dostoevsky the best way out of being a "proletarian," constantly dependent on the whim of editors. ${ }^{5}$ In June 1862,

4 The first chapters of Notes from the Dead House (Zapiski iz mertvogo doma, often translated as House of the Dead) were published in the journal Russkii mir in 1860. After Dostoevsky and his brother received permission to start their journal Vremya, publication continued there in 1861. A separate edition appeared in 1862. See PSS, 4:276-77.

5 On the history of Time and its successor journal Epoch (Epokha), see V. S. Nechaeva, Zhurnal M. M. i F. M. Dostoevskikh "Vremya," 1861-1863 (Moscow: Nauka, 1972); and Nechaeva, Zhurnal M. M. i F. M. Dostoevskikh "Epokha," 1864-65 (Moscow: Nauka, 1975). 
when the journal Time was well established, Dostoevsky wrote to one of its main contributors, Nikolai Strakhov, "A journal is a great thing [delo, also "business," "profession"]; it's the kind of activity that is no risk at all, because, whatever happens, journals as the expression of all the shades of contemporary opinions must remain. And the activity, that is, what precisely is to be done, what one must speak and write about-will always be found" (PSS, 28 [2]:26). In announcing the journal in the fall of 1860 , Dostoevsky tried to stake out a distinctive position, neither Slavophile nor Westernizer, but rather based on the idea of pochva, the native "soil" of Russia:

We know now that we cannot be Europeans, that we are not capable of squeezing ourselves into one of the Western forms of life, lived through and elaborated by Europe out of its own national [natsional'nykh] principles, which are alien and opposite to us - just as we cannot wear someone else's clothing, sewn not to our measurements. We have finally become convinced that we too are a separate nationality [natsional'nost'], original [samobytnaya] in the highest degree, and that our task is to create a new form for ourselves, our own, native one, taken out of our soil, taken out of the people's [narodnyi] spirit and out of the people's principles. (PSS, 18:36)

This idea of the need for the educated classes of Russia to merge with the common people became the consistent program of the journal and was given the label pochvennichestvo (for which no concise and adequate English translation has been coined). ${ }^{6}$

Another part of Dostoevsky's program, directed at least in part at Katkov, is his promise not to be dependent on or submissive to "literary authorities": "Golden mediocrity sometimes, even without regard to personal interest, trembles before opinions established by the pillars of literature, especially if these opinions are boldly, daringly, brazenly expressed. Sometimes only this brazenness and daring is what furnishes the designation of pillar and authority to a clever writer who knows how to make use of circumstances, and at the same time furnishes the pillar with an extreme, although temporary, influence over

6 On the idea of pochvennichestvo elaborated by the editors of and contributors to Time, see Ellen Chances, "Literary Criticism and the Ideology of Pochvennichestvo in Dostoevsky's Thick Journals Vremya and Epokha," Russian Review 34, no. 2 (1975): 151-64; and Wayne Dowler, Dostoevsky, Grigor'ev, and Native Soil Conservatism (Toronto: University of Toronto Press, 1982). 
the masses" (PSS, 18:38). This announcement appeared almost simultaneously with Evgeniya Tur's announcement of her new journal Russian Speech in the fall of 1860 . That announcement came at the end of a very public polemic between her and Katkov, a polemic to which Dostoevsky made repeated reference in his writings for Time. In that polemic Katkov's image was shaped as a man proud of his power in the literary world, arrogant and domineering. Dostoevsky's reference to the pillar of authority who brazenly and arrogantly asserts his influence resonates with the way Katkov was portrayed by Tur and her allies. And Dostoevsky's pledge to keep his journal free of "literary slavery" (ibid.) recalls Tur's pledge to avoid ideological rigidity and to honor the right to independent thought. In her announcement, Tur wrote, "Without allowing any harsh extremes, any doctrinaire attitudes, penetrated by the conviction of the necessity of all-round, independent development of social interests, of the excesses of inordinate centralization, our publication will never betray one great principle: it will not forget that respect for someone else's opinion, respect for the right to independent thought of each of the people who are striving together with us to a single goal, is the main basis for freedom of opinion." ${ }^{7}$ Katkov clearly perceived Tur's announcement as an attack on the Russian Herald, and he reacted to it accordingly.

Dostoevsky's awareness of Katkov's public image as a domineering editor full of selfish pride (samolyubie) comes through clearly in the way he reacts to Katkov in print in the early 1860s. There is a strong personal element to Dostoevsky's writings in Time that address Katkov. It is clear that Dostoevsky respects Katkov for the stature his journal has attained, but he also responds almost viscerally to Katkov's perceived arrogance and condescension. Katkov also at times makes personal attacks on Dostoevsky in the course of the polemic, no doubt conditioned by his desire to put a new upstart competitor in his place.

7 The version of Tur's announcement I had access to is "Ob izdanii G-zheiu Evgenieyu Tur v 1861 godu gazety Russkaia Rech. Obozrenie literatury, istorii, iskusstva i obshchestvennoi zhizni na zapade i v Rossii" ["About the Publication by Mrs. Evgeniia Tur in 1861 of the Newspaper Russian Speech: A Review of Literature, History, Art, and Public Life in the West and in Russia"], Moskovskie vedomosti, no. 258 (1860): 2052. See the discussion of Russkaia rech' by Jehanne Gheith, "In Her Own Voice: Evgeniya Tur, Author, Critic, Journalist" (Ph.D. diss., Stanford University, 1992), 141-65; and Gheith, Finding the Middle Ground: Krestovskii, Tur, and the Power of Ambivalence in Nineteenth-Century Russian Women's Prose (Evanston, IL: Northwestern University Press, 2004), 36-37, 42, 43, 101. 
Dostoevsky refers to Katkov with epithets such as "incontinent and quick-tempered," "limited conceit, unlimited self-satisfaction, a thirst for incense burning and worship," "petty self-worship, Jupiter-like grandeur, childish irritability." Katkov compares Dostoevsky to Gogol's empty-headed braggart Khlestakov, and at one point calls him "a fop perfumed with patchouli." ${ }^{8}$ This personal aspect of the polemic has obscured the degree to which Dostoevsky and Katkov actually agree on fundamental issues.

Dostoevsky's 1861 essay “Mr. -bov and the Problem of Art” is often seen as his aesthetic manifesto. In this essay Dostoevsky attempts to define a position independent of adherents of "pure art," on the one hand, and those now demanding that art serve a "useful" social role, on the other. ${ }^{9}$ As the editors of Dostoevsky's complete works note, Dostoevsky's position was adumbrated in his testimony in the Petrashevsky case in 1849, when he said about his literary disputes with other members of the Petrashevsky circle, "I was challenged to this literary argument, the theme of which on my side was that art does not need a [social] tendency, that art is its own aim, that the author must worry

8 Publications in which Dostoevsky addressed or alluded to Katkov that will be discussed here are "Gospodin -bov i vopros ob iskusstve," Vremya, no. 2 (1861), (will be referred to in text as "Mr. -bov"); “Obraztsy chistoserdechiia," Vremya, no. 3 (1861) ("Models of Sincerity"); “'Svistok' i 'Russkii vestnik," Vremya, no. 3 (1861) ("The Whistle and the Russian Herald"); "Otvet 'Russkomu vestniku," Vremya, no. 5 (1861) ("An Answer to the Russian Herald"); "Knizhnost' i gramotnost," Vremya, no. 7 (1861) ("Bookishness and Literacy"); and "Shchekotlivyi vopros," Vremya, no. 10 (1862) (“A Ticklish Question”). Publications in which Katkov addressed or alluded to Dostoevsky, or that Dostoevsky referred to, include "Neskol'ko slov vmesto sovremennoi letopisi," Russkii vestnik 31 (January 1861): 478-84 ("A Few Words"); "Nash iazyk i chto takoe svistuny," Russkii vestnik 32 (March 1861): 1-38 (“Our Language”); and “Odnogo polia iagody," Russkii vestnik 33 (May 1861): 1-26 ("Birds of a Feather"). References to Katkov's articles will also be cited from M. N. Katkov, Sobranie sochinenii v shesti tomakh, ed. A. N. Nikoliukin (St. Petersburg: Rostok, 2010-12); hereafter cited as SS. Dostoevsky's epithets for Katkov quoted above are from "An Answer to the Russian Herald" (PSS, 19:121, 123). Katkov called Dostoevsky "a fop perfumed with patchouli" in "Our Language," 35 (SS, 1:364). He compared Dostoevsky to Khlestakov in "Birds of a Feather," 20 (SS, 1:389, 390). Dostoevsky caricatured Katkov most pointedly in "A Ticklish Question."

9 See the notes in PSS, 18:269-92; Robert Louis Jackson, Dostoevsky's Quest for Form: A Study of His Philosophy of Art (New Haven, CT: Yale University Press, 1966); Joseph Frank, Dostoevsky: The Stir of Liberation, 1860-1865 (Princeton, NJ: Princeton University Press, 1986), 76-85; Nechaeva, Zhurnal "Vremya," 242-44; Perevalova, Zhurnal M. N. Katkova, 126-29; and V. A. Viktorovich, "'G-n -bov i vopros ob iskusstve," in Dostoevsky: Materialy i issledovaniya, no. 13 (St. Petersburg: Nauka, 1996), 227-29. See also Susanne Fusso, "Maidens in Childbirth: The Sistine Madonna in Dostoevsky’s The Devils," Slavic Review 54, no. 2 (1995): 261-75. 
only about artistic quality [khudozhestvennost'] , and the idea will come of itself; for the idea is the necessary condition for artistic quality" (PSS, 18:128-29). In "Mr. -bov," Dostoevsky chastises the advocates of "pure art" for rejecting art that has a social tendency, since that in itself constitutes a restriction on art and thus inhibits its freedom in a way that actually goes counter to their stated aims. The greater part of his article, however, is directed at Nikolai Dobrolyubov ("Mr. -bov") and other utilitarians, who neglect the key issue of artistic quality. In Dostoevsky's view, only art that is free can be of high quality, and only art that is of high quality can be of use to society. In his reading, the artistically feeble stories of Marko Vovchok that Dobrolyubov exalts because they represent the correct political position can only bring harm to that very position because of their lack of truthfulness and compelling realism.

The key passage in Dostoevsky's essay is his admonition that art will only be useful if it is freed of the demand that it be useful. No kind of preconditions can be set on art if it is to be truly artistic and therefore truly of use to humanity: "The more freely it develops, the more normally it will develop, the more quickly it will find its true and useful path. And since its interest and aim are one with the aims of humanity, whom it serves and with which it is inseparably united, then the freer its development, the more usefulness it will bring to humanity" (PSS, 18:102). As Robert Louis Jackson has pointed out, this idea is virtually identical to the view of art that Katkov formulated in his 1856 essay on Pushkin, in the very first issues of the Russian Herald: "The lines of Raphael did not solve any practical question from the everyday life contemporary to him; but they brought great good and great usefulness for life with the course of time; they powerfully contributed to the humanization of life. The action of great works of art remains not only in the sphere closest to them but spreads far and turns out to be there where there is not so much as a mention of the ideals of the artist." ${ }^{10}$

As Dostoevsky says, supposedly paraphrasing the position of the "pure art" adherents but also apparently representing his own views, "The normal historical progress of the usefulness of art in humanity is as yet unknown. It is

10 Katkov, "Pushkin," Russkii vestnik 1 (February 1856): 312 (SS, 1:266). See Jackson, Quest for Form, 38-39; and PSS, 20:288. Joseph Frank considers Dostoevsky's source to have been the writings of Valerian Maikov, but the passage he cites from Maikov concerns realism rather than usefulness, and is thus not as close to Dostoevsky's formulation as Katkov's position; see Joseph Frank, Dostoevsky: The Seeds of Revolt, 1821-1849 (Princeton, NJ: Princeton University Press, 1976), 208; see also Frank, Dostoevsky: Stir of Liberation, 84. 
hard to measure the whole mass of usefulness yielded to all humanity by, for example, the Iliad or the Apollo Belvedere, things that are apparently completely unnecessary in our time" (PSS, 18:77-78). Like Dostoevsky, Katkov in the 1856 essay on Pushkin rejects both socially didactic art and an art that is focused only on elegance of form, since both are equally far from the goal of "true art," whose value cannot be assessed either by purely social or by purely aesthetic criteria. Instead, as Katkov writes, the goal of true art is "bring[ing] life into human consciousness and consciousness into the most secret convolutions of life." 11

Katkov responded to "Mr. -bov" in his essay "Our Language and What Are Whistlers." Given the fact that Dostoevsky's basic aesthetic position in that essay is virtually the same as the one Katkov himself expounded in 1856, one might expect him to welcome Dostoevsky's entry into the discussion. He does, but only up to a point. He acknowledges that Dostoevsky's article includes "some views on art that are very sympathetic to us," but his treatment of the new journal Time as a whole is drenched in irony, and he goes on to ridicule the analysis Dostoevsky offered of Afanasii Fet's 1847 poem "Diana” in his article, "Mr. -bov."12

Dostoevsky quoted two poems by Fet in his article without giving Fet's name. The first, "Whispers, timid breathing ...," is presented as the kind of pure aestheticism that, if offered as an appropriate response to a disaster like the Lisbon earthquake, would lead to the enraged citizens' execution of the poet on the spot (PSS, 18:76). (Dostoevsky goes on to note that they might fifty years later erect a monument to him for the same poem.) The second Fet poem, "Diana," is introduced as an example of something quite different, a kind of relation to the past and the art of the past that represents not a stale imitation but a "Byronic" enthusiasm. This "Byronic" attitude arises not from "powerlessness before our own life but on the contrary from a fiery thirst for life and longing for an ideal which we are trying to attain in

11 Katkov, "Pushkin," Russkii vestnik 1 (February 1856): 315 (SS, 1:269). Much closer to the time of Dostoevsky's writing, in January 1861, Katkov referred to "art for art's sake" as a sickly art that turns into a course on aesthetics ("A Few Words" 480; SS, 1:310). Viktorovich notes the way that Dostoevsky adopts what he finds valuable from both sides of the debate (“G-n -bov," 227).

12 Katkov, “Our Language,” 15 (SS, 1:343-44). 
torments" (PSS, 18:96). The poem, which Dostoevsky quotes in full, describes a brilliantly white statue of Diana that the lyric speaker almost expects to come to life and begin to walk through the trees, to look upon Rome and its colonnades and squares. The poem concludes, "But the immobile marble / Shone white before me in incomprehensible beauty." Dostoevsky's following words are quoted by Katkov:

The last two lines of this poem are full of such passionate vitality, such longing, such significance, that we do not know anything more powerful, more vital in all of Russian poetry. This is the obsolete past, being resurrected after two thousand years in the soul of the poet, being resurrected with such power that he waits and believes, in prayer and enthusiasm, for the goddess to come down now from her pedestal and begin to walk before him, "flashing among the trees with her milky whiteness." But the goddess is not resurrected and she does not have to be resurrected, she does not have to live; she has already attained the highest moment of life; she is already in eternity, for her time has stopped; this is the highest moment of life, after which it ceases - and Olympian calm sets in. Only the future is endless, eternally calling, eternally new, and there is also its own highest moment, which one must seek and eternally seek, and that eternal seeking is called life, and how much tormenting sadness is hidden in the enthusiasm of the poet! What an endless call, what melancholy about the present in that enthusiasm for the past! $!^{13}$ (PSS, 18:97)

Again, one might expect Katkov to welcome Dostoevsky's passionate and moving appreciation of Fet's poem. At this time, two camps were clearly emerging in Russian journalism, one of which, led by Chernyshevsky and Dobrolyubov, flaunted its lack of respect for the literary traditions of the past, symbolized mainly by Pushkin. Katkov had recently begun sparring furiously with the "whistlers," a name he coined based on the name of the Whistler, the satirical supplement to the Contemporary. The "whistlers," in Katkov's parlance, as a kind of precursor term to "nihilist," were those who "move from one negation to another" and "have thrown mud on all literary authorities, have taken away Pushkin's right to the title of national [natsional'nogo] poet." ${ }^{14}$ In "Mr. -bov" Dostoevsky was also directing his main fire against Dobrolyubov

13 Quoted by Katkov, “Our Language,” 16 (SS, 1:344-45).

14 The quotation about "negation" is from Katkov, "Our Language," 11 (SS, 1:341). The quotation about Pushkin is from "A Few Words" 480 (SS, 1:310). 
and others who showed insufficient appreciation for the values of art and its historical legacy. Yet instead of embracing Dostoevsky's stance in "Mr. -bov," in particular his tribute to art and its enduring power, and the respect for the past that it inspires, Katkov characterizes Dostoevsky's interpretation of Fet's poem as far-fetched and untrue to the text. Katkov describes Dostoevsky's interpretation as "that gurgling stream of half-conceptions, half-images, and half-tones, that puts our little Russian thought to sleep so soundly, so stupefies our innocent intellectual movements, and so irresistibly inundates our humble literature." ${ }^{15}$ Katkov is being a strict formalist here; in a narrow sense he is correct that the last two lines of Fet's poem do not obviously contain on their surface all the meaning that Dostoevsky has extracted from them. But Katkov is surely being disingenuous when he pretends not to realize that Dostoevsky is creating his own prose poem inspired by Fet's verse, one that, in fact, is true to the sense of Fet's poem as a whole, even if the last two lines do not literally correspond to Dostoevsky's description. As often happens in their polemic, personal antipathy has obscured essential agreement.

The aesthetic dialogue between Katkov and Dostoevsky can be seen most vividly in their discussions of the significance of Pushkin. In his 1861 essay "A Few Words," Katkov asked, "What is Russian nationality [narodnost']? What is Russian literature, Russian art, Russian thought? Will it be advantageous for Russia that the Russian nationality and the Russian word remain behind every other nationality and every other word in Europe? Will it be good for Russia for us to remain eternal bad boy whistlers, capable only of petty deeds, of small slanders and scandals?" 16 The thrust of Katkov's argument when he asks, "What is Russian literature?," seems to be directed against Russian journalism. Yet the fact that in the parlance of the journals of the day the word "literature" was used to refer both to belles lettres and to journalistic writings makes his attack ambiguous. Dostoevsky chooses to read it as a dismissal of the achievements of Russian writers, with Pushkin at their head: "Does the Russian Herald really not see in Pushkin's talent a powerful personification of the Russian spirit and Russian meaning?” (PSS, 19:112).

15 Katkov, “Our Language," 16 (SS, 1:345).

16 Katkov, "A Few Words," 482 (SS, 1:312). 
According to the Soviet-era editors of Dostoevsky's complete works, the question of Pushkin and his significance was one of the major points of disagreement between Katkov and Dostoevsky in their polemic. The editors paint Dostoevsky as defending Pushkin against Katkov's slights. In a typical formulation, they write, “Dostoevsky's surmise about Katkov's far from enraptured personal view of Pushkin was confirmed in the further course of the polemic" (PSS, 19:297). They claim that Katkov rejected the idea of Pushkin's status as a national [narodnyi] poet. Dostoevsky says something similar about Katkov, if obliquely (19:232). ${ }^{17}$

All of this seems strange if we recall not only Katkov's lengthy essay on Pushkin published in the very first issues of the Russian Herald in 1856, but also his 1839 introduction to his translation of Varnhagen von Ense's review of Pushkin's works. Here Katkov had claimed that Varnhagen's recognition of Pushkin gave Russians the right to say "that Pushkin is a universal poet who ranks with those few on whom all of humanity looks with reverence." In that same introduction he wrote, "We are firmly convinced and clearly recognize that Pushkin is the poet not of a single epoch, but the poet of all humanity, not of a single country, but of the whole world." ${ }^{18}$ Such characterizations of Pushkin as "a universal poet [vsemirnyi poet]" and "the poet of all humanity [poet tselogo chelovechestva]" are fully in harmony with Dostoevsky's characterizations of Pushkin in his articles in Time as a poet of "universal human striving [obshchechelovecheskoe stremlenie]" (PSS, 18:99), a poet with "the capability of universality, universal humanness, universal responsiveness [sposobnost' vsemirnosti, vsechelovechnosti, vseotklika]" (19:114). ${ }^{19}$ So why is

17 See also the highly tendentious analysis of V. Ia. Kirpotin, Dostoevsky v shestidesiatye gody (Moscow: Khudozhestvennaya literatura, 1966), 96-97.

18 Katkov, "Otzyv inostrantsa o Pushkine," Otechestvennye zapiski 3, no. 5 (1839): 1-36 (SS, 1:53-84; Katkov, translation of Varnhagen von Ense's review of Sochineniia A. Pushkina [Werke von Alexander Puschkin], Jahrbücher für wissenschaftliche Kritik, no. 61, October 1838. The passage quoted is from SS, 1:55.

19 From "Mr. -bov" and "The Whistle and the Russian Herald." This characterization also lies at the basis of Dostoevsky's 1880 Pushkin speech. Marina Kanevskaya has identified a link between the Hegelian view of art expressed in Varnhagen's essay and Dostoevsky's Pushkin speech: Marina Kanevskaya, "Pushkin as 'Universal' Poet: Varnhagen von Ense and Dostoevsky," in Cold Fusion: Aspects of the German Cultural Presence in Russia, ed. Gennady Barabtarlo (New York: Berghahn, 2000), 113-25. Varnhagen's essay first appeared in Russian in Nikolai Polevoi's Son of the Fatherland (Syn otechestva) in 1839. But Katkov was unhappy with the translation, 
there the feeling throughout the polemic between Katkov and Dostoevsky that Dostoevsky has to defend Pushkin against Katkov, that Katkov does not sufficiently value Pushkin?

The answer could be that Katkov's position had changed since 1839, or even since 1856, when he had published his long essay on Pushkin's significance in the inaugural issues of the Russian Herald. But I would argue that Katkov did in fact continue to value Pushkin's contribution to Russian literature very highly, especially given that he continued to express his esteem for Pushkin to the end of his life, in the 1880s. The problem lies in the way that Katkov and Dostoevsky respectively view Pushkin's accomplishment. Dostoevsky sees it as something integral, completed, whole. Katkov sees it as an impressive but as yet unfulfilled promise of the greatness of Russian culture. When Dostoevsky read Katkov's essay on Pushkin in 1856, he wrote to a friend that Katkov's ideas were "completely opposite to mine" (PSS, 28[1]:229). Dostoevsky did not elaborate on what it was about Katkov's ideas that made them opposite to his, but it seems likely that he was not happy with Katkov's emphasis in that essay on Pushkin's contribution in shaping the Russian literary language. In 1861, in "The Whistle and the Russian Herald," Dostoevsky asks Katkov, "Did the phenomenon of Pushkin do nothing more for us than perfect [vyrabotat'] the language?" (19:112). The question implies that creating a literary language is somehow an inferior accomplishment, but that was not at all Katkov's view. In two essays of 1861, Katkov looks with envy on the High German language, which has "acquired immortal significance" and "become the palladium of a great nation [narodnost']" because of the great works of culture and thought that have been produced in it. ${ }^{20}$ Pushkin greatly advanced the cause

\footnotetext{
and, in his first act of correcting someone else's work in public, he published his own translation with an extensive introduction in Notes of the Fatherland later in 1839.

Kanevskaya cites the original translation, relegating Katkov's version to a footnote. She surmises that Dostoevsky may have learned of Varnhagen's article from N. N. Strakhov, who quoted it in an article in Notes of the Fatherland in 1867. But Strakhov's article quotes Katkov's translation of Varnhagen (and his 1856 article on Pushkin); see Strakhov, "Glavnoe sokrovishche nashei literatury," Otechestvennye zapiski, December 1867, republished in his Zametki o Pushkine i drugikh poetakh, 2nd ed. (Kiev: I. I. Chokolov, 1897), 17-34.

20 Katkov, "Our Language," 11 (SS, 1:339), and “A Few Words," 482 (SS, 1:312).
} 
of exalting Russian nationality through Russian language and literature. But for Katkov, one writer does not constitute a literary culture of world significance. Katkov wants to spur Russian literature to go further than Pushkin, to add to his accomplishment, not just sit in awed contemplation of it. It was that mission that he had espoused when he founded the Russian Herald; it was that mission that he was to further in his subsequent support of Dostoevsky's own work from 1865 to the latter's death.

In contrast to the claims of worldwide recognition of Pushkin that Katkov had expressed in 1839, in his 1861 essay "Our Language" he stresses that Pushkin has not attained universal significance on the world stage. Part of this is because of what Katkov sees as an unfinished, fragmentary legacy: "Pushkin is a great poet, and we feel that he is second to none in terms of power of creation; but tell us whether everything he achieved corresponds to those powers that one feels in him, and tell us also what Pushkin means for the rest of the world, while everywhere, and here as well, we see the powerful influence of the Byrons and Schillers?"21 In Katkov's view, Pushkin has not been recognized on the world stage partly because Russian society has not matured to the point that such recognition is deserved:

The point is not the personal powers of one or another writer, but the life of which he serves as the organ, the idea that he carries, the significance that his word has for humanity. ... The strange fate of our talents has long been noted: they disappeared from the stage at the very moment when it was just possible to expect a mature word from them; they appeared in flashes and disappeared at the very moment when they began to become a true force. As if fate wavered about whether to set going those developments that could imprint the Russian word with an immortal significance; as if it had not yet been decided whether the time had come to declare in our life the true principles that are hidden in our calling. Truly, that time has not yet come, and the life of the best minds in our milieu was and remains a life of hopes and aspirations alone. ${ }^{22}$

In his 1861 essay "Bookishness and Literacy," Dostoevsky responded angrily to Katkov's claim that Pushkin was not recognized outside Russia, and he disputed the idea that writers like Shakespeare, Schiller, and Goethe were well known to

21 Katkov, "Our Language," 17 (SS, 1:346).

22 Katkov, "Our Language," 17, 18 (SS, 1:346, 347). 
nationalities other than their own. In Dostoevsky's view, Katkov is thinking of Russians themselves, who are deeply aware of the literature of other European nations; the actual knowledge of Schiller or Shakespeare in France, for example, is in fact not that deep or broad (for some reason Dostoevsky substitutes Shakespeare for Katkov's Byron) (PSS, 19:17). But in the end he makes a statement that is not so far from Katkov's own orientation toward the possible future of Russian literature and culture rather than toward its past:

\begin{abstract}
And most importantly, how is Pushkin to blame if he is not yet known in Europe? The point is that Europe doesn't yet know Russia either: it has known it up to now only out of grave necessity. It will be another matter when the Russian element will enter as a fruitful stream into universal human development: then Europe will come to know even Pushkin, and will probably find in him incomparably more than the Russian Herald has been able to find up to this time. And then [the Russian Herald] will be ashamed in front of the Europeans! Russia is still young and is just now getting ready to live; but that is by no means a cause for blame. (PSS, 19:18)
\end{abstract}

The significance of Pushkin also lay at the heart of the major controversy in which Dostoevsky and Katkov were involved, concerning the public reading by Evgeniya Eduardovna Tolmachova, a civil servant's wife in the provincial city of Perm, of Pushkin's unfinished poem Egyptian Nights. In the section recited by Tolmachova, Cleopatra, at a public feast, offers her sexual favors to any man who is willing to sacrifice his life for one night with her. That controversy culminated in Dostoevsky's defense of Egyptian Nights from Katkov's charge that as a fragment it was unsuitable for public reading, since without being clothed in artistic detail, its potentially salacious aspects stood out more strikingly. Dostoevsky responds that Egyptian Nights is not a fragment, but "the most finished work of Russian poetry" (PSS, 19:132). ${ }^{23}$

23 In "An Answer to the Russian Herald." See Leslie O'Bell, Pushkin's "Egyptian Nights": The Biography of a Work (Ann Arbor, MI: Ardis, 1984); V. Kirpotin, "Dostoevsky o 'Egipetskikh nochakh' Pushkina," Voprosy literatury, no. 11 (1962): 112-21; Frank, Dostoevsky: Stir of Liberation, 86-87; Lewis Tracy, "Decoding Puškin: Resurrecting Some Readers' Responses to Egyptian Nights," Slavic and East European Journal 37, no. 4 (1993): 456-71; and S. V. Berezkina, "F. M. Dostoevsky i M. N. Katkov (iz istorii romana 'Prestuplenie i nakazanie')," Izvestiia RAN, Seriia literatury i iazyka 72, no. 5 (2013): 16-25. During the discussion at the conference Dostoevsky beyond Dostoevsky at Brown University in March 2014, Olga Meerson pointed out that the introductory part of Egyptian Nights is centrally concerned 
There is no question that the poem declaimed by Mrs. Tolmachova was left unfinished at Pushkin's death. But as in the disagreement between Dostoevsky and Katkov over how to interpret Fet's poem "Diana," here Katkov takes a narrow, formalistic view, while Dostoevsky reacts as a creator, not strictly an interpreter. Rather than seeing the poem's unfinishedness as a defect, Dostoevsky valorizes the very fragmentariness of Pushkin's work:

Pushkin set himself the task (if it is at all possible that he set a task in advance for his inspiration) to present a moment of Roman life, and only one moment, but in such a way as to produce by it the fullest spiritual impression, in order to convey in a few lines and images the whole spirit and meaning of that moment of the life of that time, so that by this moment, by this little corner, one could guess in advance and understand the whole picture. And Pushkin achieved this and achieved it in such artistic fullness that it appears to us as a miracle of poetic art. (PSS, 19:133)

We can see here on the micro level the same disagreement the two men had about Pushkin's legacy on the macro level: for Katkov, Pushkin's accomplishment is unfinished, an unfulfilled promise, a fragment in a sense, while for Dostoevsky, it is an integral and complete achievement.

Dostoevsky's second point is that any sexual material in the work has been transformed by a mysterious artistic process: "Here reality has been transformed, having passed through art, having passed through the fire of pure, chaste inspiration and through the poet's artistic thought. This is a secret [taina] of art, and every artist knows about it" (PSS, 19:134; emphasis in original). Third, Dostoevsky argues that if any salacious impression is received, it is the fault of the audience, not the artist: "The chastity of an image does not save it from a coarse and even perhaps a dirty thought" (ibid.; emphasis in original). Finally, he offers his own interpretation of Egyptian

with the question of usefulness in art that Dostoevsky had discussed in "Mr. -bov." But strangely neither he nor Katkov ever refers to this aspect of Egyptian Nights in the course of their polemic. On the fragmentary nature of Egyptian Nights, see the excerpt from Strakhov's unpublished article that Dostoevsky appends as a "letter" to the end of "An Answer to the Russian Herald": "Egyptian Nights is not a fragment at all. Where have you found in it signs of unfinishedness, fragmentariness? On the contrary-what a full picture! What marvelous correlation of the parts, definiteness and finishedness! ... Egyptian Nights is an improvisation, but it is a complete, finished improvisation" (PSS, 19:137-38). 
Nights as a work that produces not a "Marquis de Sade" effect but a powerful moral effect: "This ultimate expression [of passion], about which you so often talk, in our opinion can indeed be a temptation, but in our opinion it represents only the perversion of human nature, which has reached such horrible dimensions and is presented from such a point of view by the poet (and the point of view is the main thing) that it produces not an obscene but a shattering impression" (19:135; emphasis in original). Pushkin's depiction of the spiritual bankruptcy of decadent Alexandria "makes it clear to what kind of people our divine Redeemer came" (19:137). Dostoevsky is rightly celebrated for the artistically visionary interpretation of Egyptian Nights he gives in this essay.

The Tolmachova controversy provoked the most direct and personal public interaction between Dostoevsky and Katkov. It reveals some of the dynamics that would make possible the later working relationship between the two men. Most important here is that we see Dostoevsky rising to a challenge posed by Katkov. Katkov's questioning of the artistic form of Egyptian Nights inspired Dostoevsky to one of his best pieces of literary criticism. This is a kind of foreshadowing of the way in which Dostoevsky was moved to write cogently about his own artistic aims when "pitching" new ideas for novels in his letters to Katkov during the later years they worked together. We also see some of Dostoevsky's uneasiness with the radicals, whom he seems to have decided to court during his editorship of Time. Unlike M. L. Mikhailov, Dostoevsky could not defend Mrs. Tolmachova with unalloyed righteous indignation, because he felt too strongly the viewpoint of the "old mommies" whose daughters were subjected to her provocative performance. ${ }^{24}$ In this uneasiness we can see that he did not so vehemently disagree with Katkov as it would seem on the surface. But the bare-knuckled nature of nineteenth-century Russian journalism led the two men into making fairly sharp personal attacks on each other. Dostoevsky had the advantage of the clear public image of Katkov that had been developed

24 [M. L.] Mikhailov, "Bezobraznyi postupok 'Veka," Sanktpeterburgskie vedomosti, no. 51, March 3, 1861. In "Models of Sincerity," Dostoevsky had written that the opinions of the "old mommies [starykh mamenek]" in Mrs. Tolmachova's audience should be respected because of their concern for their daughters: "Indeed, for those of adolescent age such a reading might even be dangerous. In an adolescent age a person is not formed either physically or morally, and on him even the Medici Venus might not produce a fully artistic impression" (PSS, 19:103; emphasis in original). 
in the Tur polemic: the selfishly proud, overbearing, intelligent but arrogant editor throwing his weight around. Dostoevsky's public image was not as well defined at this time, but no one who knew him would have described him as a "perfumed fop"; Katkov's barb was much less apt than Dostoevsky's (but it did seem to cause Dostoevsky some pain).

Time was closed down in 1863 because of an article by Strakhov on the Polish question that was interpreted by the authorities as being seditious. By the fall of 1863, with Time closed down and a new journal not yet officially approved, Dostoevsky had fallen back into the role of a journeyman writer, or what he called a "proletarian." He wrote to Strakhov asking him to approach the editor of the Library for Reading about publishing a new work. He instructed Strakhov to make it clear that he needed to be paid in advance: "I am a proletarian writer, and if someone wants my work, he has to secure my services in advance" (PSS, 28[2]:50). Later in the same letter, Dostoevsky says that if Strakhov is unable to make a deal with the Library for Reading, then he should approach the newspapers but avoid the Notes of the Fatherland, and "of course not the Russian Herald" (PSS, 28[2]:52). After writing so many highly personal attacks on Katkov, Dostoevsky at this point could not contemplate turning to Katkov with his work. But the next two years would be some of the hardest in Dostoevsky's life and would bring him back, despite everything, to the man he first approached in 1858.

Dostoevsky spent much of 1863 in a difficult love affair with Apollinarya Suslova; his wife, Mar'ya Dmitrievna, died in April 1864 and his brother Mikhail died in July, leaving Dostoevsky to try to carry on the journal Epoch, which never really took off and closed in March 1865. Financially crushed by family needs and gambling debts, in September 1865 Dostoevsky wrote his famous letter to Katkov describing his conception of Crime and Punishment. At virtually the same time, he expressed his fears about this step in a letter to A. E. Vrangel': "While Time was being published, our two journals had some brawls. And Katkov is such a selfishly proud, vain, and vengeful person that I am very afraid now that, remembering the past, he might haughtily refuse the story I am offering and make a fool of me" (PSS, 28[2]:140). Dostoevsky saw before him in his mind's eye the caricatured, vain, and vengeful Katkov of his public polemics, which is part of the story of Katkov, but not the whole story. 
Katkov was never so selfishly proud as to lose sight of the best interests of his journal, or of the larger mission of making Russia a world-historical nation through the medium of a great literature. Contrary to Dostoevsky's fears, Katkov agreed to work with him and sent him an advance of 300 rubles for the first of the four major novels that were to secure Dostoevsky's place on the world literary stage. 
